\title{
KAJIAN KENAIKAN MUKA AIR LAUT DAN TINGGI GENANGAN (ROB) PADA TAHUN 2023, 2028, DAN 2033 DI KOTA SAUMLAKI, KABUPATEN MALUKU TENGGARA BARAT
}

\author{
Satria Ginanjar ${ }^{1 *}$, Christianti Kartika Putri' ${ }^{2}$, dan Rizkyan Nurhakim ${ }^{3}$ \\ Departemen Oseanografi, Jurusan Ilmu Kelautan, Fakultas Perikanan dan Ilmu Kelautan, \\ Universitas Diponegoro \\ Jl. Prof. Sudarto, SH Tembalang Tlp. / Fax. (024)7474698 Semarang 50275 \\ ${ }^{*}$ E-mail: satriasatriaginanjar@gmail.com
}

\begin{abstract}
ABSTRAK
Kota Saumlaki berlokasi di Kabupaten Maluku Tenggara Barat tepatnya pada Pulau Yamdena. Kota ini terletak pada wilayah pesisir yang menjadikannya bersentuhan langsung dengan kondisi eksternal seperti pasang surut. Adapun subduksi lempeng Indo-Australia dan Eurasia yang terletak di sebelah Barat Laut Saumlaki menjadikannya semakin rentan terhadap perubahan muka air laut. Penelitian ini dilakukan dengan tujuan untuk mengetahui besar kenaikan muka air laut berdasarkan analisis data pasang surut tahun 20142018 dan memprediksi tinggi genangan yang akan menutupi pantai pada 2023, 2028 dan 2033. Metode yang digunakan dalam penelitian ini adalah metode kuantitatif bersifat studi kasus. Penelitian ini menggunakan data pasang surut wilayah Saumlaki yang didapat dari Badan Informasi Geospasial (BIG) yang kemudian diolah untuk mendapatkan nilai MSL (Mean Sea Level) bulanan dan tahunan. Berdasarkan penelitian yang dilakukan diketahui laju kenaikan muka air laut Kota Saumlaki, Kabupaten Maluku Tenggara Barat adalah $3,75 \mathrm{~cm} /$ tahun dan termasuk ke dalam tipe pasang surut campuran condong ke harian ganda (Mixed SemiDiurnal) dengan bilangan Formzahl pada $2018=0,602$, nilai $M S L=383 \mathrm{~cm}$; nilai $L L W L=226,4 \mathrm{~cm}$; nilai $H H W L=541 \mathrm{~cm} ;$ nilai $\mathrm{ZO}=314 \mathrm{~cm}$. Prediksi tinggi genangan di Kota Saumlaki, Maluku Tenggara Barat pada $2023=175,75 \mathrm{~cm}$; pada $2028=194,5 \mathrm{~cm}$; dan pada $2033=213,25 \mathrm{~cm}$.
\end{abstract}

Kata kunci: kenaikan muka air laut, pasang surut, perubahan garis pantai, Kota Saumlaki, genangan rob.

\begin{abstract}
Saumlaki is located in Southeast Maluku Regency, precisely on Yamdena Island. The city is located in the coastal area which makes it in direct contact with external conditions such as tides. The subduction of the Indo-Australian and Eurasian plates is located in the northwest of Saumlaki, makes its sea level more vulnerable to changes. The objective of this research is to determine the substantial of sea level rise based on the analysis of tidal data in 2014-2018 and to predict the height of tidal inundation in 2023, 2028, and 2033. The method used in this research is the quantitative method based of case study. This research uses Saumlaki tidal data that was obtained from BIG, which is then processed to obtain monthly and annual Mean Sea Level values. Based on the research, it is known that the rate of sea level rise in Saumlaki is $3.75 \mathrm{~cm} /$ year and belongs to the type of Mixed Semi-Diurnal with Formzahl numbers in $2018=0.602$, MSL value $=383 \mathrm{~cm}$, LLWL value $=226.4 \mathrm{~cm}$, $H H W L$ value $=541 \mathrm{~cm}$, and the value of $Z O=314 \mathrm{~cm}$. Inundation prediction in Saumlaki in 2023 $=175.75 \mathrm{~cm}$, in $2028=194.5 \mathrm{~cm}$, and in $2033=213.25 \mathrm{~cm}$.
\end{abstract}

Keywords: sea level rise, tidal, coastline changes, Saumlaki, tidal inundation. 


\section{PENDAHULUAN}

\subsection{Latar Belakang}

Kota Saumlaki merupakan pusat pertumbuhan di Kabupaten Maluku Tenggara Barat dan memiliki aktivitas perekonomian yang intensif pada daerah pesisir. Saumlaki berlokasi di Pulau Yamdena yang merupakan pulau utama di Kabupaten Maluku Tenggara Barat (MTB). Pulau Yamdena terletak antara $131^{\circ} 03^{\prime} 39^{\prime \prime}-131^{\circ} 45^{\prime} 09^{\prime \prime}$ BT dan $07^{\circ} 06^{\prime}$ $13 "$ - $08^{\circ} 02$ ' $08^{\prime \prime}$ LS. Wilayah pesisir Saumlaki memiliki tingkat ancaman bencana yang relatif tinggi karena berhadapan dan berdekatan dengan subduksi lempeng IndoAustralia dan Eurasia (Prawiradisastra, 2011). Selain itu, wilayah pesisir juga sangat rentan terkena dampak dari banjir rob.

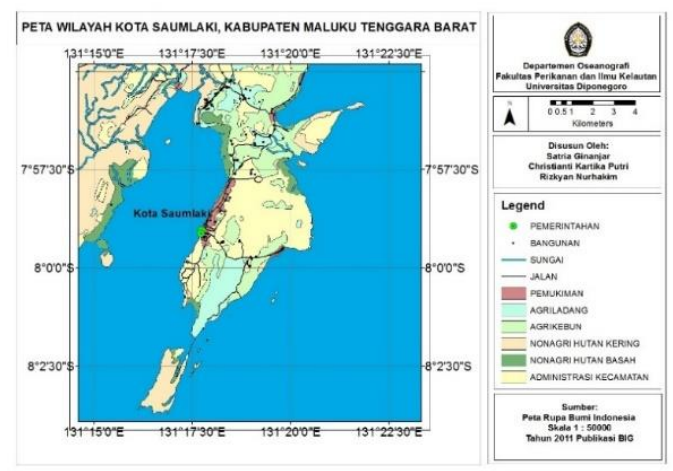

Gambar 1. Peta Wilayah Kota Saumlaki, Kabupaten Maluku Tenggara Barat.

Sumber : Pengolahan Data, 2019.

Banjir rob merupakan banjir yang diakibatkan oleh kenaikan paras muka laut. Kenaikan paras muka laut dapat disebabkan oleh pasang air laut maupun pemanasan global. Menurut Syah (2013), naiknya permukaan laut akan menyebabkan tergenangnya daerah-daerah pantai yang tidak berlereng. Kenaikan muka air laut juga akan mempertinggi abrasi pantai, merusak pemukiman, tambak, daerah pantai, dan hal lainnya pada wilayah pantai. Kenaikan paras laut ini juga dapat menenggelamkan pulau-pulau kecil.

\subsection{Perumusan Masalah}

Adapun rumusan masalah dalam penelitian ini adalah:

1. Apa jenis pasang surut yang terdapat pada wilayah Kota Saumlaki, Kabupaten Maluku Tenggara Barat?
2. Berapa kenaikan muka air laut per tahun di Kota Saumlaki?

3. Berapa tinggi genangan rob di Kota Saumlaki pada tahun 2023, 2028, dan 2033 ?

\subsection{Tujuan}

Adapun tujuan dari penelitian ini adalah:

1. Mengetahui jenis pasang surut yang terdapat pada wilayah Kota Saumlaki, Kabupaten Maluku Tenggara Barat.

2. Mengetahui kenaikan muka air laut per tahun Kota Saumlaki.

3. Mengetahui tinggi genangan rob di Kota Saumlaki pada tahun 2023, 2028, dan 2033.

\subsection{Teori}

\subsubsection{Kenaikan Muka Air Laut}

Sea Level Rise atau kenaikan muka air laut merupakan fenomena naiknya tinggi muka air laut yang merupakan akibat dari perubahan iklim yang dikaitkan dengan pemanasan global. Pemanasan global menyebabkan cairnya gletser es pada daerah kutub yang menyebabkan pertambahan pada volume air laut. Menurut Liyani dkk. (2012), perubahan tinggi muka air laut dapat dilihat sebagai suatu fenomena alam yang terjadi secara periodik maupun menerus. Perubahan secara periodik dapat dilihat dari fenomena pasang surut air laut, sedangkan kenaikan air laut yang menerus adalah seperti yang teridentifikasi oleh pemanasan global. Kenaikan muka air laut dapat menyebabkan berkurangnya atau mundurnya garis pantai, mempercepat terjadinya erosi pantai berpasir, banjir di wilayah pesisir, serta rusaknya infrastruktur yang berada di wilayah pesisir seperti dermaga, dan bangunan pantai lainnya.

\subsubsection{Pasang Surut}

Pasang surut (pasut) merupakan suatu fenomena pergerakan naik-turun permukaan air laut secara berkala yang disebabkan oleh kombinasi gravitasi bumi dan benda-benda langit (matahari dan bulan). Menurut Murtidjo (2002), semakin dekat arah putar bulan pada permukaan bumi, maka gravitasi terhadap laut akan meningkat, sehingga 
menjadikan air laut pasang. Sebaliknya, jika arah putar bulan makin menjauhi bumi, maka gravitasi terhadap laut akan menurun dan air laut menjadi surut.

Tabel 1. Jenis Pasang Surut Berdasarkan Bilangan Formzahl

\begin{tabular}{|l|l|}
\hline $\begin{array}{l}\text { Skala } \\
\text { Bilangan } \\
\text { Formzahl }\end{array}$ & Jenis Pasang Surut \\
\hline $0-0,25$ & $\begin{array}{l}\text { Harian ganda beraturan (semi } \\
\text { diurnal) }\end{array}$ \\
\hline $0,25-1,50$ & $\begin{array}{l}\text { Campuran condong ke harian } \\
\text { ganda (mixed semi-diurnal) }\end{array}$ \\
\hline $1,50-3,00$ & $\begin{array}{l}\text { Campuran condong ke harian } \\
\text { tunggal (mixed-diurnal) }\end{array}$ \\
\hline $3,00<\sim$ & $\begin{array}{l}\text { Harian tunggal beraturan } \\
\text { (diurnal) }\end{array}$ \\
\hline
\end{tabular}

1.4.3 Konstanta Harmonik Pasang Surut

Konstanta harmonik pasang surut adalah konstanta-konstanta yang dapat menyebabkan terjadinya pasang surut. Pada umumnya digunakan 9 komponen utama konstanta harmonik pasang surut untuk keperluan rekayasa, yaitu: M2, S2, K2, N2, K1, O1, P1, M4, dan MS4. Konstanta-konstanta tersebut memiliki sifat yang harmonik terhadap waktu (Sidabutar dkk., 2016).

\subsubsection{Analisis Harmonik Pasang Surut}

Analisis harmonik pasang surut adalah suatu proses pengolahan data pasut untuk mendapatkan nilai amplitudo dan beda fase konstanta harmonik pasut (Khasanah dkk., 2017). Analisis harmonik pada penelitian ini menggunakan metode admiralty. Menurut Adibrata (2007), analisis harmonik dengan metode admiralty mempunyai 3 tahapan, yaitu: tahap pertama, tahap kedua, dan tahap ketiga yang disusun dari skema 1 sampai dengan skema 8 . Tahap pertama yaitu dengan cara memisahkan komponen-komponen utama pasut berdasarkan proses hariannya. Tahap kedua yaitu dengan cara memisahkan komponen-komponen utama pasut berdasarkan proses bulanannya. Tahap ketiga merupakan tahap terakhir dimana diperoleh nilai ketinggian mean sea level $\left(\mathrm{S}_{0}\right)$ serta nilai konstanta komponen utama pasut. Nilai konstanta ini terdapat nilai

amplitudo (A, dalam centimeter) dan nilai fase ( $\mathrm{g}$, dalam derajat).
Tabel 2. Konstanta Harmonik Pasut dalam Metode Admiralty

\begin{tabular}{|c|c|c|}
\hline $\begin{array}{l}\text { Komponen } \\
\text { Pasut }\end{array}$ & Lambang & Keterangan \\
\hline \multirow[t]{4}{*}{ Semidiurnal } & $\mathrm{M}_{2}$ & $\begin{array}{l}\text { Komponen } \\
\text { utama lunar } \\
\text { semidiurnal }\end{array}$ \\
\hline & $\mathrm{S}_{2}$ & $\begin{array}{l}\text { Komponen } \\
\text { utama solar } \\
\text { semidiurnal }\end{array}$ \\
\hline & $\mathrm{N}_{2}$ & $\begin{array}{l}\text { Komponen } \\
\text { lunar akibat } \\
\text { variasi } \\
\text { bulanan jarak } \\
\text { bulan }\end{array}$ \\
\hline & $\mathrm{K}_{2}$ & $\begin{array}{l}\text { Komponen } \\
\text { soli-lunar } \\
\text { akibat } \\
\text { perubahan } \\
\text { deklinasi }\end{array}$ \\
\hline \multirow[t]{3}{*}{ Diurnal } & $\mathrm{K}_{1}$ & $\begin{array}{l}\text { Komponen } \\
\text { soli-lunar }\end{array}$ \\
\hline & $\mathrm{O}_{1}$ & \begin{tabular}{l}
\multicolumn{2}{l}{ Komponen } \\
utama lunar \\
diurnal
\end{tabular} \\
\hline & $\mathrm{P}_{1}$ & \begin{tabular}{ll}
\multicolumn{2}{l}{ Komponen } \\
utama solar \\
diurnal
\end{tabular} \\
\hline \multirow[t]{2}{*}{$\begin{array}{l}\text { Shallow } \\
\text { Water }\end{array}$} & $\mathrm{M}_{4}$ & $\begin{array}{l}\text { Komponen } \\
\text { utama } \\
\text { perairan } \\
\text { dangkal } \\
\end{array}$ \\
\hline & $\mathrm{MS}_{4}$ & $\begin{array}{l}\text { Komponen } \\
\text { utama } \\
\text { perairan } \\
\text { dangkal }\end{array}$ \\
\hline
\end{tabular}

\subsubsection{Genangan (Rob)}

Genangan rob merupakan genangan banjir pada daratan yang diakibatkan oleh pasang air laut. Menurut Mardiatno dkk. (2018), walaupun pasang surut air laut adalah faktor utama yang mencetuskan banjir ini, namun untuk kondisi dan daerah tertentu seperti di daerah terbangun, banjir pasang surut ini terjadi menyusul amblesan yang terjadi di daerah tersebut. Amblesan dapat terjadi di lahan pesisir yang tersusun oleh material lunak belum padu yang terutama dihasilkan oleh proses fluvial atau proses marine yang mendapat beban fisik di atasnya. 


\section{METODE}

\subsection{Waktu dan Tempat}

Waktu : 24 Desember 2018 - 10 Januari 2019.

Tempat: Fakultas Perikanan dan Ilmu Kelautan, Universitas Diponegoro, Semarang, Jawa Tengah.

\subsection{Cara Pengumpulan Data}

Materi penelitian ini terdiri dari data sekunder. Data sekunder merupakan data yang telah dikumpulkan oleh pihak lain, bukan oleh peneliti sendiri (Istijanto, 2009). Data sekunder pada penelitian ini berupa data pasang surut setiap bulan Juli pada tahun 2014-2018 dengan interval 1 jam hasil pengamatan Stasiun Pengamatan Pasang Surut Kota Saumlaki, Badan Informasi Geospasial yang dicatat pada website http://ioc-sealevelmonitoring.org.

\subsection{Metode Analisis Data}

Metode yang digunakan pada penelitian ini adalah metode kuantitatif bersifat studi kasus. Penelitian ini mengambil data pasang surut wilayah Saumlaki setiap jam selama 29 hari pada bulan Juli pada tahun 2014 sampai dengan 2018 yang diambil dari Badan Informasi Geospasial (BIG).

\subsection{Metode Pengolahan Data}

Metode pengolahan data yang digunakan adalah metode admiralty. Menurut Suprijanto dan Putra (2017), metode ini biasanya dipakai untuk menganalisa data hasil pengamatan pasang surut selama 15 hari atau 29 hari dengan interval waktu 1 jam. Hasil dari pengolahan data metode admiralty adalah besarnya amplitudo (Z) dan undur fase $(\mathrm{g})$ untuk 9 komponen pasang surut (M2, S2, O1, P1, N2, K2, M4, MS4) serta harga rata-rata muka air laut (mean sea level).

\section{HASIL DAN PEMBAHASAN}

\subsection{Analisa Data Pasang Surut}

Data pasang surut bulan Juli 2014-Juli 2018 diperoleh dari data hasil pengamatan Stasiun Pengamatan Pasang Surut Kota Saumlaki, Badan Informasi Geospasial. Pengolahan data pasang surut menghasilkan data pasang tertinggi dan surut terendah yang terhitung setiap hari pada bulan Juli yang ditampilkan pada

\section{Gambar 2-6.}

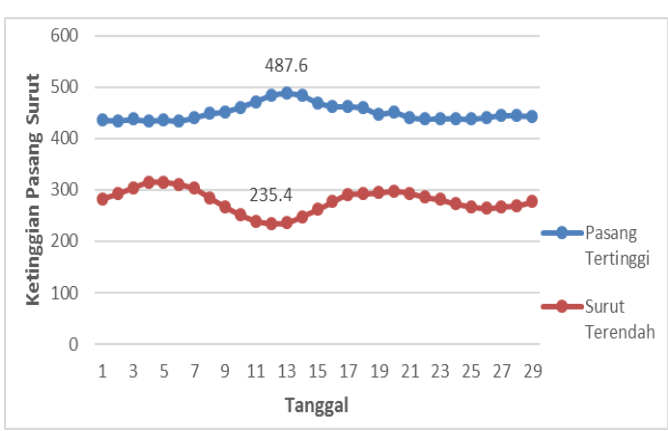

Gambar 2. Grafik Pasang Tertinggi dan Surut Terendah Bulan Juli 2014 Kota Saumlaki. Sumber: Pengolahan Data, 2019.

Berdasarkan Gambar 2, diketahui bahwa data pasang pada bulan Juli 2014 Kota Saumlaki, Maluku Tenggara Barat mencapai titik pasang paling tinggi pada tanggal 13 dengan titik pasang pada $487,6 \mathrm{~cm}$. Sedangkan titik surut terendah terjadi pada tanggal 12 dengan titik surut pada $235,4 \mathrm{~cm}$.

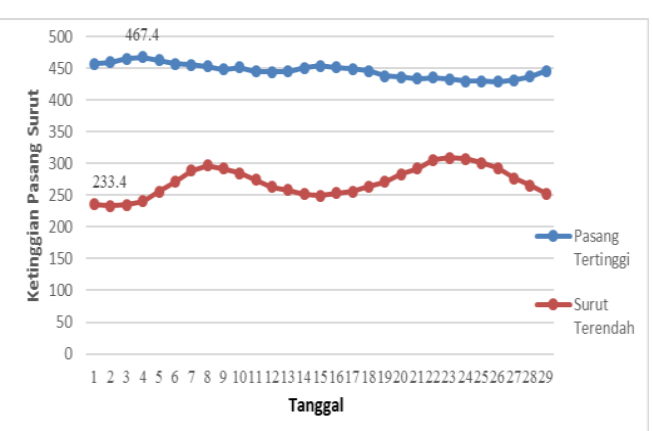

Gambar 3. Grafik Pasang Tertinggi dan Surut Terendah Bulan Juli 2015 Kota Saumlaki. Sumber: Pengolahan Data, 2019.

Berdasarkan Gambar 3, diketahui bahwa pada data pasang surut bulan Juli 2015 Kota Saumlaki terjadi pasang tertinggi pada tanggal 4 dengan titik pasang pada $467,4 \mathrm{~cm}$ dan surut terendah terjadi pada tanggal 2 dengan titik surut pada $233,4 \mathrm{~cm}$. Gambar 4. Grafik Pasang Tertinggi dan Surut Terendah Bulan Juli 2016 Kota Saumlaki.

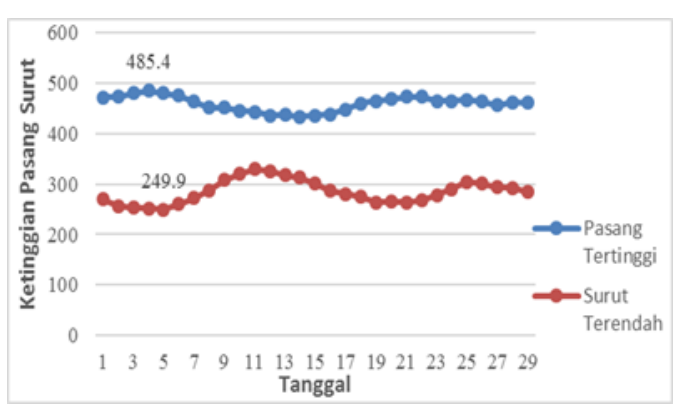


Sumber: Pengolahan Data, 2019.

Berdasarkan Gambar 4, diketahui bahwa pada data pasang surut bulan Juli 2016 Kota Saumlaki terjadi pasang tertinggi pada tanggal 4 dengan titik pasang pada $485,4 \mathrm{~cm}$ dan surut terendah pada tanggal 5 dengan titik surut pada $249,9 \mathrm{~cm}$.

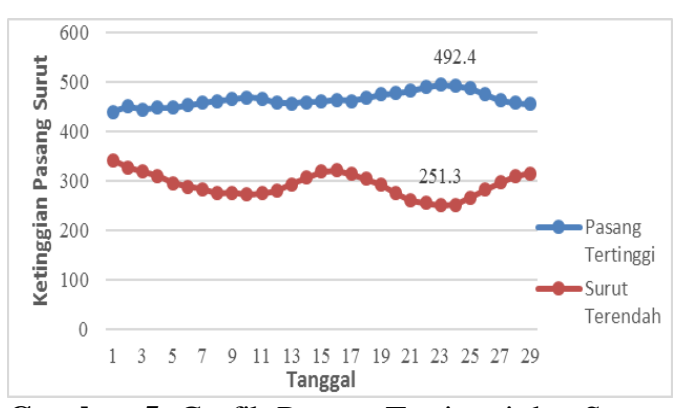

Gambar 5. Grafik Pasang Tertinggi dan Surut Terendah Bulan Juli 2017 Kota Saumlaki.

Sumber: Pengolahan Data, 2019.

Berdasarkan Gambar 5, diketahui bahwa pada data pasang surut bulan Juli 2017 Kota Saumlaki terjadi pasang tertinggi pada tanggal 24 dengan titik pasang pada $492,4 \mathrm{~cm}$ dan surut terendah pada tanggal 23 dengan titik surut pada $251,3 \mathrm{~cm}$.

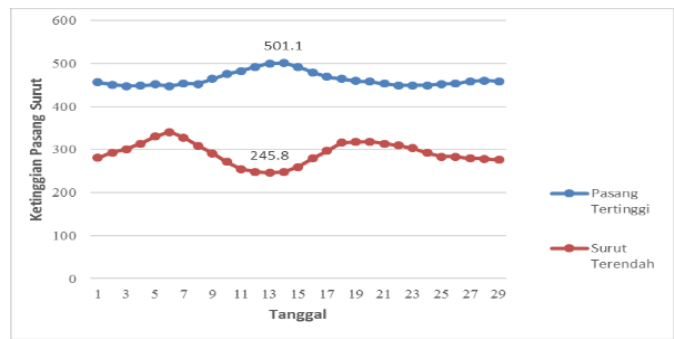

Gambar 6. Grafik Pasang Tertinggi dan Surut Terendah Bulan Juli 2018 Kota Saumlaki.

Tabel 3. Konstanta Harmonik Pasang Surut Bulan Juli 2014 Kota Saumlaki, Kabupaten Maluku Tenggara Barat.

\begin{tabular}{|l|l|l|l|l|l|l|l|l|l|l|}
\hline & $\mathrm{S}_{0}$ & $\mathrm{M}_{2}$ & $\mathrm{~S}_{2}$ & $\mathrm{~N}_{2}$ & $\mathrm{~K}_{1}$ & $\mathrm{O}_{1}$ & $\mathrm{M}_{4}$ & $\mathrm{MS}_{4}$ & $\mathrm{~K}_{2}$ & $\mathrm{P}_{1}$ \\
\hline $\mathrm{A}(\mathrm{Cm})$ & 369 & 61 & 13 & 4 & 39 & 15 & 6 & 4 & 4 & 13 \\
\hline $\mathrm{g}^{\circ}$ & & 490 & 346 & 422 & 83 & 449 & 680 & 502 & 346 & 83 \\
\hline
\end{tabular}

F

$$
\begin{aligned}
& =\left(O_{1}+K_{1}\right) /\left(M_{2}+S_{2}\right) \\
& =(15+39) /(61+13) \\
& =0,729
\end{aligned}
$$

a. Mean Sea Level (MSL)

MSL $=\mathrm{S}_{0}$

$$
=369 \mathrm{~cm}
$$

b. Lowest Low Water Level (LLWL)

$\mathrm{LLWL}=\mathrm{AS}_{0}-\mathrm{A}\left(\mathrm{M}_{2}+\mathrm{S}_{2}+\mathrm{K}_{1}+\mathrm{O}_{1}+\mathrm{P}_{1}+\mathrm{K}_{2}\right)=211 \mathrm{~cm}$
Sumber: Pengolahan Data, 2019.

Berdasarkan Gambar 6, diketahui bahwa pada data pasang surut bulan Juli 2018 Kota Saumlaki terjadi pasang tertinggi pada tanggal 14 dengan titik pasang pada $501,1 \mathrm{~cm}$ dan surut terendah pada tanggal 13 dengan titik surut pada $254,8 \mathrm{~cm}$. Pasang tertinggi dan surut terendah berdasarkan grafik sangat dipengaruhi oleh peristiwa gaya tarik bumi dan bulan.

\subsection{Analisa Komponen Pasang Surut}

Data pasang surut 29 hari di bulan Juli menggunakan metode admiralty. Pengolahan data pasang surut menggunakan metode admiralty menghasilkan konstanta harmonik dan nilai formzahl. Konstanta pasang surut yang dihasilkan antara lain: $\mathrm{S}_{0}, \mathrm{M}_{2}, \mathrm{~S}_{2}, \mathrm{~N}_{2}$, $\mathrm{K}_{2}, \mathrm{~K}_{1}, \mathrm{O}_{1}, \mathrm{P}_{1}, \mathrm{M}_{4}$, dan $\mathrm{MS}_{4}$. Konstanta harmonik digunakan untuk mencari nilai MSL, HHWL, LLWL, dan ZO. Hasil pengolahan data pasang surut bulan Juli 2014-2018 diperoleh nilai konstanta harmonik pasang surut yang dapat dilihat pada Tabel 3-7. 2014-Juli 2018 Kota Saumlaki diolah 
Tabel 4. Konstanta Harmonik Pasang Surut Bulan Juli 2015 Kota Saumlaki, Kabupaten Maluku Tenggara Barat.

\begin{tabular}{|c|c|c|c|c|c|c|c|c|c|c|}
\hline & $\mathrm{S}_{0}$ & $\mathrm{M}_{2}$ & $\mathrm{~S}_{2}$ & $\mathrm{~N}_{2}$ & $\mathrm{~K}_{1}$ & $\mathrm{O}_{1}$ & $\mathrm{M}_{4}$ & $\mathrm{MS}_{4}$ & $\mathrm{~K}_{2}$ & $\mathrm{P}_{1}$ \\
\hline $\mathrm{A}(\mathrm{Cm})$ & 363 & 65 & 13 & 4 & 40 & 10 & 6 & 4 & 4 & 13 \\
\hline $\mathrm{g}^{\circ}$ & & 253 & 347 & 63 & 83 & 180 & 150 & 240 & 347 & 83 \\
\hline
\end{tabular}

a. Mean Sea Level (MSL)

MSL $=\mathrm{S}_{0}$

$$
=363 \mathrm{~cm}
$$

b. Lowest Low Water Level (LLWL)

$\mathrm{LLWL}=\mathrm{AS}_{0}-\mathrm{A}\left(\mathrm{M}_{2}+\mathrm{S}_{2}+\mathrm{K}_{1}+\mathrm{O}_{1}+\mathrm{P}_{1}+\right.$ $\mathrm{K}_{2}$ )

$$
=205 \mathrm{~cm}
$$

c. Highest High Water Level (HHWL)

$\mathrm{HHWL}=\mathrm{AS}_{0}+\mathrm{A}\left(\mathrm{M}_{2}+\mathrm{S}_{2}+\mathrm{K}_{1}+\mathrm{O}_{1}+\mathrm{P}_{1}+\right.$ $\mathrm{K}_{2}$ )

$$
=522 \mathrm{~cm}
$$

d. ZO (muka surutan)

$\mathrm{ZO}=\mathrm{HHWL}-\mathrm{LLWL}$

$=318 \mathrm{~cm}$

Tabel 5. Konstanta Harmonik Pasang Surut Bulan Juli 2016 Kota Saumlaki, Kabupaten Maluku Tenggara

\begin{tabular}{|l|l|l|l|l|l|l|l|l|l|l|}
\hline & $\mathrm{S}_{0}$ & $\mathrm{M}_{2}$ & $\mathrm{~S}_{2}$ & $\mathrm{~N}_{2}$ & $\mathrm{~K}_{1}$ & $\mathrm{O}_{1}$ & $\mathrm{M}_{4}$ & $\mathrm{MS}_{4}$ & $\mathrm{~K}_{2}$ & $\mathrm{P}_{1}$ \\
\hline $\mathrm{A}(\mathrm{Cm})$ & 377 & 66 & 20 & 4 & 30 & 22 & 5 & 6 & 5 & 10 \\
\hline $\mathrm{g}^{\circ}$ & & 12 & 337 & 148 & 6 & 350 & 27 & 348 & 337 & 6 \\
\hline
\end{tabular}

a. Mean Sea Level (MSL)

$$
\begin{aligned}
\text { MSL } & =\mathrm{S}_{0} \\
& =377 \mathrm{~cm}
\end{aligned}
$$

b. Lowest Low Water Level (LLWL)

$$
\begin{array}{cl}
\underset{\mathrm{LLWL}}{\left.\mathrm{O}_{1}+\mathrm{P}_{1}+\mathrm{K}_{2}\right)} & =\mathrm{AS}_{0}-\mathrm{A}\left(\mathrm{M}_{2}+\mathrm{S}_{2}+\mathrm{K}_{1}+\right. \\
& =210 \mathrm{~cm}
\end{array}
$$

c. Highest High Water Level (HHWL)

$$
\begin{gathered}
\mathrm{HHWL} \\
\left.\mathrm{O}_{1}+\mathrm{P}_{1}+\mathrm{K}_{2}\right)
\end{gathered}=\mathrm{AS}_{0}+\mathrm{A}\left(\mathrm{M}_{2}+\mathrm{S}_{2}+\mathrm{K}_{1}+\right.
$$

d. ZO (muka surutan)

$$
\begin{aligned}
& \mathrm{ZO}=\mathrm{HHWL}-\mathrm{LLWL} \\
& =333 \mathrm{~cm}
\end{aligned}
$$

Tabel 6. Konstanta Harmonik Pasang Surut Bulan Juli 2017 Kota Saumlaki, Kabupaten Maluku Tenggara Barat.

\begin{tabular}{|l|l|l|l|l|l|l|l|l|l|l|}
\hline & $\mathrm{S}_{0}$ & $\mathrm{M}_{2}$ & $\mathrm{~S}_{2}$ & $\mathrm{~N}_{2}$ & $\mathrm{~K}_{1}$ & $\mathrm{O}_{1}$ & $\mathrm{M}_{4}$ & $\mathrm{MS}_{4}$ & $\mathrm{~K}_{2}$ & $\mathrm{P}_{1}$ \\
\hline $\mathrm{A}(\mathrm{Cm})$ & 383 & 63 & 20 & 4 & 30 & 26 & 5 & 6 & 5 & 10 \\
\hline $\mathrm{g}^{\circ}$ & & 105 & 338 & 119 & 360 & 95 & 214 & 82 & 338 & 360 \\
\hline
\end{tabular}

$$
F \quad=\left(O_{1}+K_{1}\right) /\left(M_{2}+S_{2}\right)
$$

$$
=(26+30) /(63+20)
$$$$
=0,674
$$

a. Mean Sea Level (MSL)

$$
\begin{aligned}
\text { MSL } & =\mathrm{S}_{0} \\
& =383 \mathrm{~cm}
\end{aligned}
$$

b. Lowest Low Water Level (LLWL)

LLWL $=\mathrm{AS}_{0}-\mathrm{A}\left(\mathrm{M}_{2}+\mathrm{S}_{2}+\mathrm{K}_{1}+\mathrm{O}_{1}\right.$ $\left.+\mathrm{P}_{1}+\mathrm{K}_{2}\right)$

$$
\mathrm{ZO}=\mathrm{HHWL}-\mathrm{LLWL}
$$

$$
=213 \mathrm{~cm}
$$

c. Highest High Water Level (HHWL)

HHWL $=\mathrm{AS}_{0}+\mathrm{A}\left(\mathrm{M}_{2}+\mathrm{S}_{2}+\mathrm{K}_{1}+\mathrm{O}_{1}\right.$ $\left.+\mathrm{P}_{1}+\mathrm{K}_{2}\right)$ $=553 \mathrm{~cm}$

d. ZO (muka surutan) 
Tabel 7. Konstanta Harmonik Pasang Surut Bulan Juli 2018 Kota Saumlaki, Kabupaten Maluku Tenggara

\begin{tabular}{|l|l|l|l|l|l|l|l|l|l|l|}
\hline & $\mathrm{S}_{0}$ & $\mathrm{M}_{2}$ & $\mathrm{~S}_{2}$ & $\mathrm{~N}_{2}$ & $\mathrm{~K}_{1}$ & $\mathrm{O}_{1}$ & $\mathrm{M}_{4}$ & $\mathrm{MS}_{4}$ & $\mathrm{~K}_{2}$ & $\mathrm{P}_{1}$ \\
\hline $\mathrm{A}(\mathrm{Cm})$ & 384 & 57 & 21 & 4 & 30 & 17 & 6 & 6 & 6 & 10 \\
\hline $\mathrm{g}^{\circ}$ & & 199 & 346 & 155 & 356 & 321 & 42 & 185 & 346 & 356 \\
\hline
\end{tabular}

F

$$
\begin{aligned}
& =\left(O_{1}+K_{1}\right) /\left(M_{2}+S_{2}\right) \\
& =(17+30) /(57+21) \\
& =0,602
\end{aligned}
$$

a. Mean Sea Level (MSL)

$$
\begin{aligned}
\mathrm{MSL} & =\mathrm{S}_{0} \\
& =384 \mathrm{~cm}
\end{aligned}
$$

b. Lowest Low Water Level (LLWL)

$$
\begin{aligned}
\mathrm{LLWL} & =\mathrm{AS}_{0}-\mathrm{A}\left(\mathrm{M}_{2}+\mathrm{S}_{2}+\mathrm{K}_{1}+\mathrm{O}_{1}\right. \\
\left.+\mathrm{P}_{1}+\mathrm{K}_{2}\right) & =226 \mathrm{~cm}
\end{aligned}
$$

Berdasarkan hasil pengolahan data pasang surut bulan Juli 2014-Juli 2018 yang diperoleh dari Stasiun Pengamatan Pasang Surut Kota Saumlaki, Badan Informasi Geospasial diperoleh bilangan formzahl bulan Juli 20142018 masing masing yaitu 0,$729 ; 0,641$; 0,$604 ; 0,674$; dan 0,602. Berdasarkan bilangan formzahl dapat diketahui bahwa jenis pasang surut di wilayah Kota Saumlaki, Kabupaten Maluku Tenggara Barat termasuk ke dalam jenis pasang surut campuran condong ke harian ganda (mixed semidiurnal). Menurut Prarikeslan (2017), pasang surut campuran condong ke harian ganda adalah jenis pasang surut yang terjadi dua kali pasang dan dua kali surut dalam satu hari, namun tinggi dan periodenya berbeda. Jenis pasang surut ini banyak terjadi di perairan Indonesia bagian timur.

\subsection{Analisis Kenaikan Muka Air Laut}

\subsubsection{Kenaikan Muka Air Laut Rara Rata (MSL)}

Perhitungan laju kenaikan muka air laut rata-rata dilakukan dengan menggunakan data pasang surut 5 tahun setiap bulan Juli dari tahun 2014-2018 hasil pengamatan Stasiun Pengamatan Pasang Surut Kota Saumlaki, Badan Informasi Geospasial. Nilai kenaikan muka air laut rata-rata diperoleh dari perhitungan data pasang surut dengan metode

$$
\begin{aligned}
& \text { c. Highest High Water Level (HHWL) } \\
& \begin{array}{ll}
\mathrm{HHWL} & =\mathrm{AS}_{0}+\mathrm{A}\left(\mathrm{M}_{2}+\mathrm{S}_{2}+\mathrm{K}_{1}+\mathrm{O}_{1}\right. \\
\left.+\mathrm{P}_{1}+\mathrm{K}_{2}\right) & =541 \mathrm{~cm}
\end{array} \\
& \begin{aligned}
& \mathrm{ZO} \text { d } \mathrm{ZO} \text { (muka surutan) } \\
& \mathrm{ZO}=\mathrm{HHWL}-\mathrm{LLWL} \\
&=314 \mathrm{~cm}
\end{aligned}
\end{aligned}
$$

admiralty. Nilai kenaikan muka air laut ratarata tahunan di Stasiun Pengamatan Pasang Surut Kota Saumlaki, Badan Informasi Geospasial pada 2014-2018 berturut-turut adalah $369 \mathrm{~cm}, 363 \mathrm{~cm}, 377 \mathrm{~cm}, 383 \mathrm{~cm}$, dan $384 \mathrm{~cm}$. Gambar 7 menunjukan grafik kenaikan muka air laut rata-rata tahunan Juli 2014-Juli 2018.

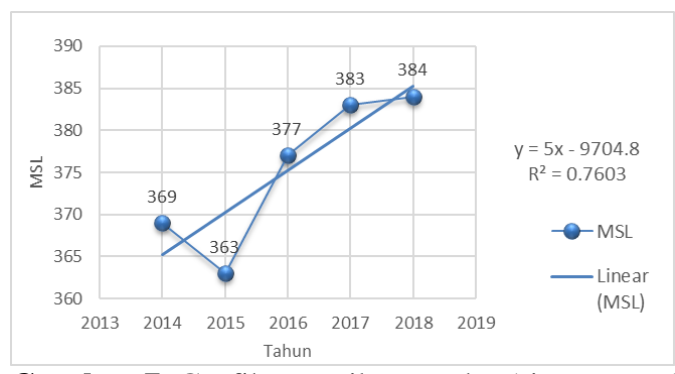

Gambar 7. Grafik Kenaikan Muka Air Laut Bulan Juli 2014 - Juli 2018 Kota Saumlaki.

Sumber: Pengolahan Data, 2019.

Berdasarkan Gambar 7, sumbu Y merupakan kenaikan muka air laut rata-rata dan sumbu $\mathrm{X}$ merupakan variabel waktu pengamatan pada bulan Juli 2014-2018. Berdasarkan Gambar 7, didapat kecenderungan kenaikan muka air laut rata-rata dengan persamaan $\mathrm{y}=5 \mathrm{x}-$ 9704,8 dengan nilai $R^{2}=0,7603$. Nilai $R^{2}$ merupakan hubungan antara kenaikan muka air laut rata-rata (MSL) dengan waktu pengamatan dengan persentase sebesar $76,03 \%$, sedangkan $23,97 \%$ merupakan faktor yang dipengaruhi oleh 
gejala alam Super El Niño atau yang dinamai NASA sebagai "Godzilla El Niño" yang berakibat pada penurunan drastis nilai kenaikan muka air laut rata-rata pada bulan Juli 2015. Pada tahun 2017 dan 2018 juga terjadi El Niño dengan skala anomali tidak setinggi pada tahun 2015, sehingga pengaruh El Niño pada MSL di 2017 dan 2018 sangat kecil.

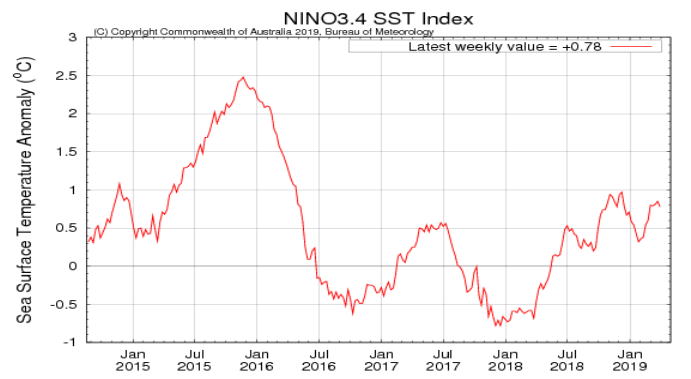

Gambar 8. Grafik NINO3.4 SST Index

Sumber: Bureau of Meteorology, 2019

Laju kenaikan muka air laut rata-rata diperoleh dari penjumlahan nilai rata-rata selisih kenaikan muka air laut dari tahun ke tahun antara tahun 2014-2018. Laju kenaikan muka air laut rata-rata adalah $3,75 \mathrm{~cm} / \mathrm{tahun}$. Selisih nilai MSL tahunan yang dihitung dari 2014-2018 ditampilkan dalam Tabel 8.

Tabel 8. Laju Kenaikan Muka Air Laut Rata-rata (MSL) Tahun 2014-2018

\begin{tabular}{|l|l|l|}
\hline Tahun & MSL & Selisih \\
\hline 2014 & 369 & -6 \\
\hline 2015 & 363 & 14 \\
\hline 2016 & 377 & 6 \\
\hline 2017 & 383 & 1 \\
\hline 2018 & 384 & \\
\hline Rata-rata & & 3,75 \\
\hline
\end{tabular}

\subsubsection{Highest Hight Water Level (HHWL)}

Perhitungan highest hight water level (HHWL) menggunakan data pasang surut bulan Juli 2014-Juli 2018 Kota Saumlaki hasil pengamatan Stasiun Pengamatan Pasang
Surut Kota Saumlaki, Badan Informasi Geospasial. Nilai HHWL diperoleh dari perhitungan data pasang surut dengan metode admiralty. Nilai HHWL bulan Juli 2014-2018 berturut-turut adalah $527 \mathrm{~cm}, 522 \mathrm{~cm}, 544 \mathrm{~cm}$, $553 \mathrm{~cm}$, dan $541 \mathrm{~cm}$.

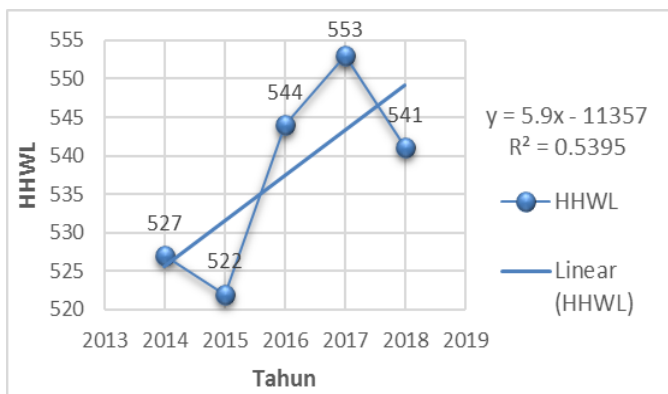

Gambar 9. Grafik HHWL Bulan Juli 2014 - Juli 2018 Kota Saumlaki.

Sumber: Pengolahan Data, 2019.

Berdasarkan Gambar 9, Sumbu Y merupakan skala HHWL dan Sumbu $X$ merupakan variabel waktu pengamatan pada bulan Juli 2014-Juli 2018. Berdasarkan Gambar 9, kecenderungan HHWL dengan persamaan y = $5,9 x-11375$ dan $R^{2}=0,5395$. Nilai $R^{2}$ merupakan hubungan antara HHWL dengan variabel waktu dengan persentase 53,95\%, persentase ini menunjukan hubungan antara HHWL dengan variabel waktu yang cukup besar. Sedangkan $46,05 \%$ sisanya merupakan faktor-faktor yang dipengaruhi oleh gejala alam Super El Niño yang berakibat pada penurunan drastis nilai HHWL pada bulan Juli 2015, serta faktor lain yang tidak dijelaskan dalam kajian ini.

\subsubsection{Lowest Low Water Level (LLWL)}

Perhitungan lowest low water level (LLWL) menggunakan data pasang surut bulan Juli 2014-Juli 2018 Kota Saumlaki hasil pengamatan Stasiun Pengamatan Pasang Surut Kota Saumlaki, Badan Informasi Geospasial. Nilai LLWL diperoleh dari perhitungan data pasang surut dengan metode admiralty. Nilai LLWL bulan Juli 2014-2018 berturut-turut adalah $211 \mathrm{~cm}, 205 \mathrm{~cm}, 210 \mathrm{~cm}$, $213 \mathrm{~cm}$, dan $226 \mathrm{~cm}$. 


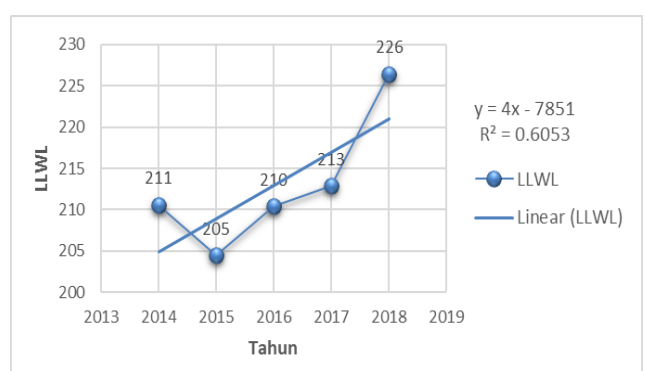

Gambar 10. Grafik LLWL Bulan Juli 2014 - Juli 2018 Kota Saumlaki.

Sumber: Pengolahan Data, 2019.

Berdasarkan Gambar 10, Sumbu Y merupakan skala LLWL dan Sumbu $X$ merupakan variabel waktu pengamatan pada bulan Juli 2014-Juli 2018. Berdasarkan Gambar 10, kecenderungan LLWL dengan persamaan $\mathrm{y}=4 \mathrm{x}-7851$ dan $\mathrm{R}^{2}=0,6053$. Nilai $R^{2}$ merupakan hubungan antara LLWL dengan variabel waktu dengan persentase $60,53 \%$, persentase ini menunjukan hubungan antara LLWL dengan variabel waktu yang cukup besar. Sedangkan $39,47 \%$ sisanya merupakan faktor yang dipengaruhi oleh gejala alam Super El Niño yang berakibat pada penurunan drastis nilai LLWL pada bulan Juli 2015 serta faktor lain yang tidak dijelaskan dalam kajian ini.

\subsection{Analisis Tinggi Genangan}

Berdasarkan pengolahan data MSL pada Tabel 8, ditunjukan bahwa rata-rata kenaikan muka air laut di Kota Saumlaki adalah $3,75 \mathrm{~cm} /$ tahun. Nilai rata-rata kenaikan air laut digunakan untuk menghitung prediksi tinggi genangan pada tahun 2023, 2028, dan 2033. Besarnya prediksi tinggi genangan di Kota Saumlaki dapat dilihat pada perhitungan di bawah ini.

Tinggi genangan pada 2018

$$
\begin{aligned}
& =\text { HHWL } 2018-\text { MSL } 2018 \\
& =541-384 \\
& =157 \mathrm{~cm}
\end{aligned}
$$

Prediksi Genangan $=$ Tinggi Genangan 2018

$+\left(\right.$ kenaikan muka laut* $\left.\left(\mathrm{t}_{1}-\mathrm{t}_{0}\right)\right)$

$\mathrm{t}_{0}=$ tahun awal

$\mathrm{t}_{1}=$ tahun akhir

Tinggi genangan pada 2023

$=157+\left(3,75^{*}(2023-2018)\right)$

$=175,75 \mathrm{~cm}$
Tinggi genangan pada 2028

$$
\begin{aligned}
& =157+\left(3,75^{*}(2028-2018)\right) \\
& =194,5 \mathrm{~cm}
\end{aligned}
$$

Tinggi genangan pada 2033

$$
\begin{aligned}
& =157+\left(3,75^{*}(2033-2018)\right) \\
& =213,25 \mathrm{~cm}
\end{aligned}
$$

\section{KESIMPULAN}

Kesimpulan yang diperoleh dari penelitian ini adalah jenis pasang surut di wilayah Kota Saumlaki, Kabupaten Maluku Tenggara Barat merupakan jenis pasang surut campuran condong ke harian ganda (mixed semidiurnal) dengan bilangan formzahl pada data Juli $2018=0,602$. Hasil dari rata-rata MSL 2014-2018 menunjukkan kenaikan muka air laut yang terjadi di wilayah Kota Saumlaki adalah $3,75 \mathrm{~cm} /$ tahun. Prediksi tinggi genangan rob pada $2023=175,75 \mathrm{~cm} ; 2028=$ $194,5 \mathrm{~cm}$; dan $2033=213,25 \mathrm{~cm}$.

\section{UCAPAN TERIMA KASIH}

Penulisan makalah yang berjudul "Kajian Kenaikan Muka Air Laut dan Tinggi Genangan (ROB) Pada Tahun 2023, 2028, dan 2028 di Kota Saumlaki, Kabupaten Maluku Tenggara Barat" dapat terlaksana dengan baik berkat bantuan, arahan, dorongan, dan bimbingan dari berbagai pihak. Oleh karena itu penulis mengucapkan terima kasih yang sebesar besarnya kepada.

1. Orang Tua

2. Bapak Dr. Denny Nugroho S, S.T, M.Si selaku Kepala Departemen Oseanografi

3. Moch. Reza Fahlevi yang telah memberikan pengarahan dan bimbingan

\section{DAFTAR PUSTAKA}

Prawiradisastra, S., 2011. Analisis Kerawanan dan Kerentanan Bencana Gempabumi dan Tsunami untuk Perencanaan Wilayah di Kabupaten Maluku Tenggara Barat. Jurnal Sains dan Teknologi Indonesia 13 (2): 103-107.

Syah, A. F., 2013. Pengukuran Daerah Genangan di Pesisir Bangkalan Akibat Naiknya Muka Air Laut. Jurnal Ilmiah Perikanan dan Kelautan 5 (1): 67. 
Liyani, Kriyo S., Suntoyo, 2012. Analisa Perubahan Garis Pantai Akibat Kenaikan Muka Air Laut di Kawasan Pesisir Kabupaten Tuban. Jurnal Teknik POMITS 1 (1): 1

Murtidjo, B. A., 2002. Budi Daya dan Pembenihan Bandeng. Yogyakarta: Penerbit Kanisius. $111 \mathrm{hlm}$.

Sidabutar, Y. L., B. Sasmito, F. J. Amarrohman, 2016. Analisis Sea Level Rise dan Komponen Pasang Surut dengan Menggunakan Data Satelit Altimetri JASON-2. Jurnal Geodesi Undip 5 (1): 245

Khasanah I. U., S. Wirdinata, Q. Guvil, 2017. Analisis Harmonik Pasang Surut untuk Menghitung Nilai Muka Surutan Peta (Chart Datum) Stasiun Pasut Sibolga. Prosiding Seminar Nasional Strategi Pembangunan
Infrastruktur ke-3 (SPI-3). ITP, Padang.

Adibrata, S., 2007. Analisis Pasang Surut di Pulau Karampuang, Provinsi Sulawesi Barat. Jurnal Sumberdaya Perairan 1 (1): 1-2.

Mardiatno D., B. Susilo, E. T. W. Mei, 2018. Potensi Sumberdaya Pesisir Kabupaten Jepara. Yogyakarta: Gadjah Mada University Press. 227 hlm.

Istijanto, M.M., 2009. Aplikasi Praktis Riset Pemasaran. Jakarta: Gramedia.

Suprijanto H. dan Putra S. M. B., 2017. Buku Ajar Teknik Pantai. Malang: UB Press. $229 \mathrm{hlm}$.

Prarikeslan, W., 2016. Oseanografi. Jakarta: K E N C A N A. 199 hlm. 